\title{
PORT SECURITY VS ECONOMIC GAIN: AN EXPOSITION OF THE MALAYSIAN PORT AND MARITIME SECURITY PRACTICE
}

\author{
Abdulkadir O. Abdulrazaq* \\ Sharifah Zubaidah Syed Abdul Kader**
}

\begin{abstract}
Seaports represent economic development and act as focal points in the global strategic environment. The economic contribution through seaports of Malaysia relies heavily on safe passage of merchant ships through the Straits of Malacca and at Malaysian ports. The economic advantages to the Malaysian government due to the presence of the surrounding sea are enormous. However, these economic advantages through the ports are not without their own challenges as ships that call to unload are vulnerable to shipment of dangerous cargo and weapons. The question is whether the government should enhance the monitoring of foreign ships that unload at Malaysian ports bringing enormous economic gains to Malaysia? This paper recommends
\end{abstract}

Ph.D (IIUM, Malaysia), LL.M (Ile-Ife, Nigeria), LL.B (Ilorin, Nigeria), BL, Lecturer, Department of Private and Property Law, Faculty of Law, University of Ilorin, Nigeria.E-mail: kor181law@gmail.com.

Associate Professor, Ahmad Ibrahim Kulliyyah of Laws, International Islamic University Malaysia. E-mail: sharifahz@iium.edu.my. 
that economic gain should not be given priority over port security as the former may not be capable of remedying the havoc that could result through negligence in the latter.

Keywords: Port, Maritime, Security, Economic Gain.

\title{
KESELAMATAN PELABUHAN IWn KEUNTUNGAN EKONOMI SATU HURAIAN BERKAITAN AMALAN KESELAMATAN PELABUHAN DAN MARITIM MALAYSIA
}

\begin{abstract}
ABSTRAK
Pelabuhan melambangkan pembangunan ekonomi dan bertindak sebagai titik tumpu dalam persekitaran strategik sejagat. Sumbangan ekonomi melalui pelabuhan Malaysia bergantung harap kepada laluan selamat kapal-kapal dagang melalui Selat Melaka dan di pelabuhan-pelabuhan Malaysia. Kelebihan ekonomi kepada kerajaan Malaysia akibat dari kewujudan laut sekitar adalah amat besar. Walau bagaimanapun, kelebihan ekonomi melalui pelabuhan ini mempunyai cabaran yang tersendiri; memandangkan kapal yang berlabuh untuk memunggah barang muatan terdedah kepada penghantaran barangan dan senjata yang berbahaya. Persoalannya adalah sama ada pihak kerajaan perlu meningkatkan pemantauan terhadap kapal asing yang memunggah barang muatan di pelabuhan Malaysia dan membawa keuntungan ekonomi yang besar kepada Malaysia. Kertas ini mencadangkan bahawa keuntungan ekonomi tidak patut diberikan keutamaan berbanding dengan keselamatan pelabuhan memandangkan keuntungan ekonomi mungkin tidak mampu memperbetulkan
\end{abstract}


kekacauan yang boleh terhasil akibat kecuaian dalam keselamatan pelabuhan.

Kata kunci: pelabuhan, maritime, keselamatan, keuntungan ekonomi.

\section{INTRODUCTION}

Ports of a nation play a key role in the states' security and economic advancement. This is because a port serves as a route for the import and export of cargoes worth billions of dollars while generating job opportunities for the state concerned. Malaysia is one of the countries that is endowed with extensive sea access culminating in the establishment of ports, an opportunity that eludes a landlocked state. Ports as well as inland waterways like those found in Malaysia are used to move crude oil, cargo containers, minerals, bulk agricultural and paper products, to mention but a few. Moreover, a port is considered as a critical factor in national security, hence ports generally host security agencies like navies, immigration officers, customs, marine police, etc. The presence of naval bases in a port usually facilitates the movement of military paraphernalia along with troops overseas ${ }^{1}$ in case of symmetric maritime security threat. The need to secure a nation's ports and maritime domain against a restless realm of sea ${ }^{2}$ and other possible terrorist attacks has become a topical in the recent years. ${ }^{3}$ Maritime security is an issue of strategic importance, particularly to countries in the Asia-Pacific because of its vital economic

$1 \quad$ See Maritime Security, Information-Sharing Efforts are Improving. Available at GAO-06-933T Maritime Information -Sharing are Improving Adobe Reader (Viewed on 27/8/12). p. 4.

2 Murphy M.N, “Lifeline or Pipedream? Origins, Purposes, and Benefits of Automatic Identification System, Long-Range Identification and Tracking, and Maritime Domain Awareness," in Herbert-Burns .R, Bateman S, Lehr P, Lloyd's MIU Handbook of Maritime Security, (United States of America: CRC Press, 2009), p. 13.

$3 \quad$ Shicun. W and Keyuan. Z, "Maritime Security in the Southern China Sea: Cooperation and Implications,” in Shicun. W and Keyuan. Z, (ed), Maritime Security in the South China Sea: Regional Implications and the International Cooperation (England: Ashgate Publishing Ltd, 2010), p. 3. 
relevance. Malaysia, like other port states, gives priority to security priorities in view of the terrorist attacks on the World Trade Centre and Pentagon on September 11, 2001 in United States of America. ${ }^{4}$ On the basis above, this article examines the priority given to port security by the Malaysian government vis-à-vis the economic benefits accruable to it from loading and unloading of goods at her ports. Port security encompasses the following in general:

i. The principle of state assertion of national sovereignty over ports;

ii. Domestic legislation which regulates port authorities and the adoption of port regulations, conditions for admission of ships, etc; and

iii. Maritime agencies which oversee enforcement, safety, security, rights and obligations of port service providers such as pilots, towage, shipping agents; the liabilities of ship owners vis-à-vis port authorities.

In order to address maritime security issues in Malaysia, the Malaysian government has ratified a series of conventions. These include the United Nations Convention on the Law of the Sea (UNCLOS) 1982, Safety of Life at Sea Convention (SOLAS) 1974, Load Lines Convention 1996, Civil Liability Convention 1969, Standards of Training, Certification and Watch Keeping Convention (STCW) 1978, Agreement on the

Balanoi R.C, "Maritime Security Threat in Post-9/11 Southeast Asia: Regional Responses,” in Herbert-Burns. R, Bateman. S, Lehr. P, Lloyd's MIU Handbook of Maritime Security, (United States of America: CRC Press, 2009), p. 253. See also Tsamenyi. M, Palma. M.A and Schofield. C, "International Legal Regulatory Framework for Seafarers and Maritime Security Post-9/11” in Herbert-Burns. R, Bateman. S, Lehr. P, Lloyd's MIU Handbook of Maritime Security, (London: CRC Press, 2009), p. 233 and Ke XU, "Myth and Reality: The Rise and Fall of Contemporary Maritime Piracy in the South China Sea” in Shicun. W and Keyuan. Z, (ed), Maritime Security in the South China Sea: Regional Implications and the International Cooperation (England: Ashgate Publishing Ltd, 2010), 81. 
International Association of Lighthouse Authorities Maritime Bouyage System, 1982 etc. In addition, the Parliament of Malaysia enacted the Malaysian Maritime Enforcement Agency Act in $2004^{5}$ which established the Malaysian Maritime Enforcement Agency (MMEA) with jurisdiction in the Malaysian Maritime Zones. ${ }^{6}$ Prior to the establishment of the MMEA, there were about eight agencies in existence enforcing over 40 federal laws, agreements and regulations in Malaysia. ${ }^{7}$ One of the main objectives for setting up the MMEA was to resolve the interface between the security agencies with regard to operations, functions and jurisdictions ${ }^{8}$ in maritime domain.

\section{MALAYSIA'S APPROACH TO SEA}

Since ancient times, the Malays have always considered the seas bordering their country as natural appurtenances and therefore under its absolute control and sovereignty. This idea of ownership of the seas emphasises the unity of the country's land and water that is reflected in the Malay term "land-water." Malaysia as a country signed the United Nations Convention on the Law of the Sea, 1982 (UNCLOS) on $10^{\text {th }}$ December 1982 but ratified it fourteen years later, specifically on $14^{\text {th }}$ October,

5 This Act came into force on February 15, 2005. It was published in the Gazette on July 1, 2004.

$6 \quad$ See Section 2 of the Act.

7 Irwin U.J. Ooi, “The Malaysian Maritime Enforcement Agency Act 2004: Malaysia’s Legal Response to the Threat of Maritime Terrorism,” (2007), Australian \&New Zealand Maritime Law Journal, 21, 75. See also Zulkifli Bin Abu Bakar, "Strengthening Comprehensive and Cooperative Security in the Asia Pacific: Enhancing Maritime SecurityLaw Enforcement in Malaysia.” Available at www.isis.org.my/files/ 24APRWEB/Zulkifli_Abu_Bakar.pdf (accessed on 27/11/12).

Ibid.

'Tanah-air' which is literally translated to mean 'Land-water.' It was presumably not a suprise to Sir Stamford Raffles who founded Singapore in 1819 to find in the course of his many far Eastern exploits, the existence of Malaysia's first law of the sea in a codified form which first made its appurtenance as far back as the year 1276 during the reign of Sultan Muhammed Shah, the first sovereign of Malacca. 
1996. ${ }^{10}$ In addition to being a party to the UNCLOS, Malaysia is a party to many other maritime and ocean related treaties that have influenced the use and management of Malaysia's marine environment. ${ }^{11}$

Historically, peoples of the South-east Asia region (Malaysia inclusive) have in general organised their lives within the context of the seas surrounding their land. The Malays who are living in coastal areas in particular firmly consider the sea as a natural appurtenance to the land they occupy. ${ }^{12}$ Malaysia as a sovereign state exercises jurisdiction and absolute sovereignty in seas such as the Straits of Malacca, the Sulu Sea, the Celebes Sea and the South China Sea which encompass the Malay Peninsula and the Malay Archipelagos. A vivid indication of absolute sovereignty of Malaysia in Sulu Sea was demonstrated recently when Malaysia, through her military troops, resisted invasion through its maritime waters by Mindanao insurgents at Lahad Datu. The Moro Islamic Liberation Front (MILF) troops sneaked into part of Malaysia through water, and although its activities were curtailed, about twelve (12) Malaysian police men were killed in the confrontation. ${ }^{13}$ The attempt by the Moro Islamic Liberation Front (MILF) at Lahad Datu was made towards realisation of the Bangsamoro nation and thereby claiming sovereignty over Sabah which is part of Malaysia. Malaysia as a sovereign state has absolute right to protect its sovereignty and territorial integrity. However, it has been stated that the manifestations of sovereignty by states are not in any way absolute because sovereignty can be compromised one way or another. Thus, despite a state being independent

10 After the ratification of the LOSC, the Malaysian Ministry of Foreign Affairs issued a Declaration concerning Malaysia's position with regard to certain provisions in the LOSC.

11 For example, Safety of Life at Sea Convention (SOLAS), 1974, Load Lines Convention, 1996, Civil Liability Convention, 1969, Standards of Training, Certification and Watch Keeping Convention (STCW) 1978, Agreement on the International Association of Lighthouse Authorities Maritime Bouyage System, 1982 etc.

12 Tunku Sofiah Jewa, Law of the Sea in Public International Law: A Malaysian Perspective, Vol. II, (Kuala Lumpur: Pacifia publications, 1996), p. 634.

13 This incident started in the first week of March, 2013. 
and sovereign, part of its territories could be subject to overlapping claims as it is the situation with Mindanao over Sabah. ${ }^{14}$

The seas surrounding the land played an important role in the economic, defence and political matters of the state. Malaysia presently has a plethora of maritime laws which regulate transportation and movement of cargo and passengers through its seas and borders. However, it has been asserted that the influence accorded by the development of world-wide laws of the sea since the advent of Western European dominance in ocean-related matters ${ }^{15}$ prompted the establishment of a rather irregular mix of international and national legislations in Malaysia. Malaysia's first national law on the management of internal waters was in 1920 in the form of the Water Act, which provided for the control of rivers and streams.

\section{(a) Malaysia's Protection of National Interests in Maritime Security}

Malaysia is one of the counties that value its border security either at sea ports or airports. Accordingly, Malaysia became involved directly in pursuing national interests at the international level regarding maritime jurisdiction in order to ensure security and self-preservation, resource exploration and exploitation as well as political well-being. Thus, to achieve the above, Malaysia adopted the Sectoral Approach in formulating maritime or ocean related laws for the administration of the maritime sector. ${ }^{16}$ However, due to the overlapping of functions and jurisdictions,

\footnotetext{
$14 \quad$ See Haniff Ahamat, "The Mindanao Conflict and its Impact on Malaysia: Between National Sovereignty and Regional Cooperation," being a paper presented at a symposium on, Bangsamoro Framework Agreement and the Role of Malaysia, organised by Ahmad Ibrahim Kulliyyah of Laws, IIUM on 23 $3^{\text {rd }}$ May, 2013.

15 Gold .E, Maritime Transport -The Evolution of International Marine Policy and Shipping Law, (Toronto: D.C Heath and Company, 1981).

16 Malaysia was one of the many developing countries which advocated for the expansion of maritime zones culminating in the concept of the Exclusive Economic Zone (EEZ). The establishment of the EEZ by a coastal state meant that the coastal state shall have sovereign rights to benefit from the exploration and exploitation of the resources within expanded zones, among other rights and responsibilities.
} 
the sectoral approach was dropped for a Singular Approach which culminated in the enactment of the Malaysian Maritime Enforcement Agency Act 2004 and subsequent establishment of the Malaysian Maritime Enforcement Agency which is now coordinating all port and maritime security agencies. Whether the MMEA has been able to achieve its mandates vis-à-vis coordination of maritime security is not within the purview of this discourse but will be a topical issue in another paper.

It needs to be emphasised that Malaysia is yet to be a party to a number of international conventions that may be considered useful for meaningful management of Malaysia's sea areas and diverse maritime activities. Therefore, ratification and subsequent adoption of these conventions into the national legislation will facilitate and legalise certain powers of the country with regard to the enforcement, administration and control of maritime activities. It is clear that Malaysia has not given the domestication of some conventions the required attention. These conventions include International Maritime Organisation (IMO) conventions like Intervention Convention 1969, 1923 International Convention and Statute on the Regime of Maritime Ports, Protocol of 1992 to amend the International Convention on the Establishment of an International Fund for Compensation for Oil Pollution Damage, 1971, etc.

\section{(b) Economic Sustainability Through Maritime Cooperation}

No state can combat transnational crimes alone without the aid of other states. Economic development and sustainability in maritime commerce are achievable through cooperation of coastal states to fight the menace of maritime insecurity. Although, Malaysia has been wary about pressure from the U.S on the exchange programme between her MMEA officers and the U.S Coast Guard, perhaps loss of jurisdiction over the maritime domain and opposition to some U.S policies might be the reason for Malaysia's unwillingness. ${ }^{17}$ However, cooperation among neighbouring

$17 \quad$ Kawamura. S, "Multilateral Cooperation in the Asian-Pacific Region and the Role of U.S-Japan Alliance,” in Andrew A. (ed), Maritime Capacity Building in the Asia-Pacific Region, (Sea Power Centre: Australia, 2010), 182. 
coastal states will enhance enforcement operations, and the latter requires solid international cooperation. ${ }^{18}$ There have been measures to combat counter-terrorism cooperatively through the Five Power Defence Arrangements (FPDA) which consists of Australia, Britain, Malaysia, Singapore and New-Zealand. The concern over maritime security has attracted the attention of external powers, thereby bringing about rivalry within the region. The U.S tried to improve security in the Straits of Malacca with the aid of regional allies but China has expressed concern over the U.S. ability to disrupt its access. ${ }^{19}$

Since the MMEA has been established as the sole agency of maritime security surveillance in Malaysia, it needs to be empowered to represent Malaysia in the FPDA. The government needs to assert its participation in the FPDA and establish control through the MMEA and other similar agencies in other jurisdictions with regards to maritime surveillance. These arrangements must be carried out within their maritime domains, and any offender caught should be decisively dealt with and punished. The states under the arrangement must not harbor criminals and must be ready to either extradite any offender to the maritime zone of the country where the offence is committed or prosecute such offender. Thus, where there is a strong cooperation among the regional coastal states, international ships that fail to abide by rules and regulations in conducting regional business in the region will find it difficult to traverse the international strait.

\section{MALAYSIA'S POWERS AND RESPONSIBILITIES OVER THE STRAITS OF MALACCA}

The Straits of Malacca is an important sea lane in Southeast Asia 600 miles in length and it connects the Indian Ocean with the South China Sea and is the major sea lane used by tankers from the Middle East. ${ }^{20}$

\footnotetext{
$18 \quad$ See Andrew TH Tan, “The Asian Countries’ Interest in Asian Energy Security,” in Forbes. A, (ed), 47.

Ibid.

HO, J.H, "Southeast Asian SLOC Security," Maritime Security in the South China Sea, Regional Implications and International Cooperation, in Shicum Wu and Keyuan Zou, (eds), (England, Asghate Publishing Ltd, 2009), 158.
} 
Enforcement of the MMEA against vessels in this busy shipping route is limited because the Strait is regarded as being 'used for international navigation.' The term "straits used for international navigation" contained under part III of the 1994 Law of the Sea Convention means that a coastal state like Malaysia cannot deny foreign vessels right of access/ passage through the lane. ${ }^{21}$ This is unlike the right of innocent passage where the coastal states like Malaysia have the right to suspend passage of foreign ships on the reason of national security. ${ }^{22}$ However, notwithstanding the provisions of the law contemplating the straits as being used for international navigation, Malaysia as a coastal state in collaboration with other coastal states, like Singapore, Indonesia, etc. could still find solace in Article 43 of the 1982 UNCLOS which provides for the rights of coastal states to maintain and preserve the marine environment of the straits and to decline right of access to foreign ships that are vulnerable. The MMEA has a daunting task in surmounting the challenges and saving the country from national insecurity.

It would be recalled that during the period of negotiation of the 1982 UNCLOS, maritime states were in support and insisted that the Straits remain open for navigation but the bordering states were averse to the idea and contended that those straits are within their territorial sea and therefore not international waters. Accordingly, after long deliberations, the committee of nations in their wisdom attempted to satisfy both the interests of the maritime states and states bordering the straits and it was concluded that the term 'international straits' contained in the UNCLOS be replaced with "straits used for international navigation." 23 This provision will enable Malaysia as a port and coastal state to exercise certain rights as mentioned earlier on foreign flagged vessels traversing the Straits of Malacca.

$21 \quad$ Navigation of foreign vessels could only be suspended by the coastal states where passage causes serious damage marine environment of the straits. See UNCLOS 1982, Article 233.

$22 \quad$ UNCLOS 1982, Article 25(3).

$23 \quad$ See for example Articles 34 and 41 of the UNCLOS 1982. See also Mohd Hazmi Bin Mohd Rusli, p. 81 and Mohd Hazmi Bin Mohd Rusli, “The Application of Transit Passage in Straits Used for International Navigation: A Study of the Straits of Malacca and Singapore,” (2012), Asian Politics and Policy, Vol. 4, No. 4, 550-553. 


\section{FREEDOM OF THE HIGH SEAS}

The principle of freedom of the high seas ${ }^{24}$ does not apply to ports and this has culminated in several attempts to establish for foreign flagged ships right of access to ports. The right of access to ports is considered as corollary of a foreign flagged ship to enter into the ports of another state known as port state. As mentioned earlier, the 1923 Convention on the International Regime of Maritime Ports was the first treaty dealing with this issue ${ }^{25}$ and it makes provision for reciprocity by states to the convention, allowing access to ships of all member states.

By the principle of public international law, states are under obligation to open their ports to foreign ships except in a situation where the vital interests of the states will be jeopardised. ${ }^{26}$ There appears to be a dichotomy on the issue of foreign ships' access to ports of other states as could be gleaned from controversy among scholars. ${ }^{27}$ It has been

$24 \quad$ See Article 87 of UNCLOS provides for the freedom of the high seas: "the high seas are open to all States whether coastal or land-locked and it also comprises, inter alia...(a) freedom of navigation." Article 2 which provides that: "Subject to the principle of reciprocity and to the reservation set out in the first paragraph of Art. 8, every Contracting State undertakes to grant the vessels of every other Contracting State equality of treatment with its own vessels, or those of any other State whatsoever, in the maritime ports situated under its sovereignty or authority, as regards freedom of access to the port, the use of the port, and the full employment of the benefits as regards navigation and commercial operations which it affords to vessels, their cargoes and passengers. The equality of treatment thus established shall cover facilities of all kinds, such as allocation of berths, loading and unloading facilities, as well as dues and charges of all kinds levied in the name or for the account of the government, public authorities, concessionaries or undertakings of any kind."

26 Connell. D.P.O, The International Law of the Sea, Vol. II (Oxford: Clarendon Press, 1984) 848. See also the case of Saudi Arabia v Arabian American Oil Company (ARAMCO) (1958) 27 I. L. R. 117.

$27 \quad$ See Abdulkadir O.A and Sharifah Zubaidah Syed Abdul Kader, "Right of Ship Access to Port State Under International Law: All Bark with No Bite,” (2012), Australian Journal of Basic and Applied Sciences, 6(11), pp. 215-216. Tasikas. V, “The Regime of Maritime Port Access: A Relook at Contemporary International and United States Law" (2007), Loyola Maritime Law Journal, 5 loy.mar L.J 1, p. 1. 
asserted that the right of access is usually granted by treaty between the states concerned, ${ }^{28}$ however the general view is that there is no such separate customary right. ${ }^{29}$ It appears that a more accepted view is that the port states are entitled to prescribe and enforce circumstances under which foreign ships will be granted right to port entry. ${ }^{30}$ It has been maintained that coastal states enjoy the power to regulate ships' access to their ports by virtue of sovereign rights ${ }^{31}$ in spite of the rule of international law that ports of states must be open to foreign ships. Some authors agree that the right of access to ports exists in favour of foreign ships, but others believe in rationalising that states are legally obligated to maintain open ports, based on the general right and interest of free trade and navigation existing between states in question. Nevertheless, this view is far from certain as the legal position and argument of scholars expressed above were apparently in opposition to each other. Consequently, scholars have ${ }^{32}$ refuted the idea that ports of a state are presumed open under international law irrespective of economic interest accruable to port states. They maintain that customary international law does not in any way advocate a general notion of a right of port state access and invents no basis for a right of entry into maritime ports.

\section{Limitation of the 1982 UNCLOS on Port Security}

It is certain that man has exploited the sea for centuries which no doubt frequently led to conflict. ${ }^{33}$ However, with the adoption of the UNCLOS

\footnotetext{
$28 \quad$ Klein N, Maritime Security and the Law of the Sea, (Oxford, University Press, 2010), p. 66.

29 De La Fayyette. L, “Access to Ports in International Law,” (1996) 1, International Journal of Marine and Coastal Law, pp. 1 1-2.

$30 \quad$ Ibid at p. 30. See also Nicaragua v US (Merits) [1986] ICJ Rep, 14, 111 para 213.

31 Ibid.

32 Tasika. V, at $\mathrm{p} 2$.

33 The exploration of the resources of the sea by man has resulted in series of conflicts over ownership right of the inland-waters as recently decided by the court in Cameroon v Nigeria (2002) I.C.J 430 and same equally between Myanmar v Bangledesh decided on 14/3/12 by the
} 
1982, the international community has created a comprehensive legal framework for the governance of the sea which, over time, has evolved into powerful law. But as is the case with other legal frameworks, it cannot provide an answer to every problem that arises. It is taken that the international law of the sea comprises of all the legal norms pertaining to the sea as well as to relations between states. It also contains rules on the exploitation and delimitation of maritime areas as well as provisions on the protection and exploration of the oceans. It is also interesting to note that UNCLOS makes provisions for right of innocent passage of foreign flagged ships through the territorial sea. ${ }^{34}$ Some fields fall outside its scope and these include matters covered by national legislation, such as regulations on port ssecurity. It is axiomatic then that a country will not compromise its national security with economic gain arising from right of access of foreign ships to its ports.

The issue of foreign flagged ships' right of access to port states is guided by the provisions of the 1923 Convention and Statute on International Regime of Maritime Ports which provides as follows:

"Subject to the principle of reciprocity and to the reservation set out in the first paragraph of Article 8, every Contracting State undertakes to grant the vessels of every other Contracting State equality of treatment with its own vessels, or those of any other State whatsoever, in the maritime ports situated under its sovereignty or authority, as regards freedom of access to the port, the use of the port, and the full enjoyment of the benefits as regards navigation and commercial operations which it affords to vessels, their cargoes and passengers. The equality of treatment thus established shall cover facilities of all kinds, such as allocation of berths, loading and unloading facilities, as well as dues

International Tribunal for the Law of Sea. The judgment is available at http://docs.google.com/viewer?a=cache:KBXo_yDTLwJ:www.itlos. org/fileadmin/itlos/ (accessed on 2/4/12). Apparently, this would hinder maritime activities and indeed the economic development of not only the conflicting parties, but the world in general.

$34 \quad$ See Article 17. 
and charges of all kinds levied in the name or for the account of the Government, public authorities, concessionaries or undertakings of any kind.”35

The right of a port state like Malaysia to deny access to a foreign flagged ship may occur where the exercise of the right of access by such a ship would constitute danger. Imminent danger may occur through importation of weapons and harmful substances that are considered inimical to the peace and orderliness of a state. The importation of such items which might pose danger especially where it is done without the knowledge of government, thereby threatening the national security of the port states concerned, enables Malaysia as a port state to deny such right of access and the power of denial should ordinarily be regulated by domestic laws. Article 3 of the 1923 Convention provides that:

"The provisions of the preceding Article in no way restrict the liberty of the competent port authorities to take such measures as they may deem expedient for the proper conduct of the business of the port provided that these measures comply with the principle of equality of treatment as defined in the said Article.”

The power of a state to regulate entry of vessels into her ports was reinstated by the U.S Congress when it stated thus:

"The port State may condition entry of a foreign ship into its internal waters or ports on compliance with its laws and regulations. [It] may also exercise jurisdiction to enforce international standards with respect to some activities that occurred prior to entry into its ports or internal waters (for example, illegal discharge of pollutants)."36

$36 \quad$ The Congress was quoted and referred to in Oliver J.T, "Legal and Policy Factors Governing the Imposition of Conditions on Access to and Jurisdiction over Foreign-Flag Vessels in U.S. Ports,” (2009), South Carolina Journal of Internal Law and Business, Vol. 5 Issue 2 , p. 216. 
In the case of Khedivial Line $v$ Seafarers' International Union, ${ }^{37}$ a United Arab Republic owned merchant vessel was denied access to the port of New York, wherein the plaintiff sought interalia, an injunctive relief and damages based on the international right of access. The court in deciding the case stated as follows:

"Plaintiff concedes that there is no treaty between the United States and the United Arab Republic granting the latter's vessels free access to United States ports. Plaintiff has presented no precedents or argument to show either that the law of nations accords an unrestricted right of access to harbors by vessels of all nations or that, if it does, this is a right of the foreign national rather than solely of the nation. In any event the law of nations would not require more than comity to the ships of a foreign nation, and here they are cause of the picketing is a harassment of American shipping and seaman by the United Arab Republic that is not denied.”

It is almost sacrosanct that one of the most critical factors motivating global economic development and progress in recent times is no doubt the freedom to participate in seaborne trade the world over. The fact that foreign ships to a large extent enjoy unrestricted right of access to port states is an important element of the global economic success and development story. ${ }^{38}$ Accordingly, the right of access of foreign flagged

Also, on the right of port state to close its port against a foreign vessel that fails to meet its entry requirements, see Kaye. S, "Threats from the Global Commons: Problems of Jurisdiction and Enforcement,” (2007) Vol. 8, Melbourne Journal of International Law .

$37 \quad$ 278 F. 2d 49, (2d Cir. 1960).

38 Sharifah Zubaidah Syed Abdul Kader and Abdulkadir. O.A, "Privatization of Maritime Security Surveillance and Enforcement: A Compromise of State Sovereignty,” (2013) Vol. 9, Journal of Law, Policy and Globalization, p. 19. See also Oliver J.T., "Legal and Policy Factors Governing the Imposition of Conditions on Access to and Jurisdiction Over Foreign-Flag Vessels in U.S. Ports,” (2009) Vol. 5, South Carolina Journal of International Law and Business, pp. 209-210. See also 
ships to Malaysian ports granted under the 1923 Convention and other treaties to participate in seaborne trade like other security concern has its challenges. The serious threats posed to global peace and order by international terrorism has given rise to all important national security issues among the port states. This development is having its bite with respect to the right of access by foreign ships to port states, therefore the security question is now a factor to be reckoned with in port accessibility. ${ }^{39}$ Other vital concerns in this regards like illegal immigration, drug trafficking, illegal fishing, unsafe oil tankers, threats to the marine environment, violation of customs laws, etc. also prompted port states to impose conditions on right of access to ports. These have culminated into enactment of laws like Immigration Act, Ports Authority Act, Customs Act, etc in Malaysia to prevent importation of arms and ammunition through border ports without due regard to law.

In an attempt to increase their economic fortune, Malaysia like other port states allows ships from different countries to patronise its ports by way of the import and export of goods. In order to avert attendant security challenges associated with the freedom of navigation and participation in seaborne trade, Malaysia also joined comity of nations to regulate ingress and egress of ships to their ports. Regulations in this regard including Safety of Life at Sea Convention (SOLAS) 1974, 1923 International Convention and Statute on the Regime of Maritime Ports, International Convention for the Prevention of Pollution from Ships (MARPOL Convention) 73/78, etc. have been adopted by states.

Malaysia as a coastal nation has the privilege even to exclude foreign ships and exercise wide control over the territorial sea but cannot deny the right of innocent passage to ships of foreign nations. ${ }^{40}$ The high seas which are regarded as International waters is not subject to the

Rahaman C., Evolving U.S Framework for Global Maritime Security from 9/11 to the 1000-ship Navy in Herbert-Burns. R. Bateman. S, and Lehr. P. Lloyd's MIU Handbook of Maritime Security, (United States of America: CRC Press, 2009), pp. 39-40.

39 Sharifah Zubaidah Syed Abdul Kader and Abdulkadir O.A, ibid. p. 19.

40 Mohammed Naqib Ishan Jan, Principles of Public International Law: Modern Approach, (Malaysia: IIUM, 2009), p. 259-260. See also Hardani. A, "Critical Analysis of the Right of Innocent Passage in the Territorial Sea,” (2005) 5 MLJ, Malaysian Law Journal Article, xliii, p. 5. 
jurisdiction or control of a singular nation because it is outside the territorial sea. It is on this basis that ships enjoy a certain degree of freedom of navigation while on the high seas. In the case of Shellers $v$ Maritime Security Inspector, ${ }^{41}$ the court held that the domestic legislation of a coastal or port state cannot impose conditions on foreign flagged ships on the high seas.

\section{PORT SECURITY AND GATT 1947/WTO 1994}

The General Agreement on Tariffs and Trade (GATT) in its preamble recognises the need for entering into mutually beneficial arrangements towards substantial elimination of discriminatory treatment in international commerce..$^{42}$ In other words, it is recognised that in order to promote maritime commerce, states are enjoined not to discriminate against foreign flagged ships that visit ports of coastal states. Thus, GATT promotes freer international trade by requesting contracting states to carry out their commercial relations in accordance with the principle of the mostfavoured-nation and national treatment. ${ }^{43}$

However, in order to ensure that shipping activities are carried out in line with the trading practices and national legislations, customs officials of a port state concerned play a vital role in the port and maritime security. For state customs to achieve their objectives in ensuring adequate security vis-à-vis importation of dangerous cargo, there is a need for a new security regime. This new security regime may include not just existing national maritime institutions, but it may also extend to security and customs organisations which could be formedd in conjunction with the World Customs Organisation. For instance, the United States has

$41 \quad$ (1999) CA 2 NZLR 44.

$42 \quad$ See the preamble to GATT 1947.

43 Wilkinson. R, Multilateralism and the World Trade Organisation, (London: Routlegde, 2000), pp. 20-23. See also Articles I and III of the GATT. See also Grossman G.N, "United States-Defensive Safeguard Measures on Imports of Circular Welded Carbon Quality Line Pipe from Korea not for Attribution" in Horn. H and Mavroidis P.C (ed), The Two WTO Case Law of 2002, (Cambridge University Press: New York, 2005), p. 108, Qureshi A.H and Ziegler A.R, International Economic Law, $3^{\text {rd }}$ ed. (London: Sweet and Maxwell, 2011), pp. 66-67. 
obtained the WCO and European Union support for its CSI program and as a result, the U.S Customs launched a program known as "CustomsTrade Partnership Against Terrorism (C-TPAT). The main goal of this program is to identify and eliminate weaknesses in its container import supply chains which include unvented foreign suppliers, shippers and procedures. This has been put in place with the aim of reducing the potentiality of smuggling weapons and delaying of inspection which may not be favourable to shippers. ${ }^{44}$ The World Customs Organisation promotes trade and of course open market across the world in accordance with the natural concomitants of globalisation. ${ }^{45}$

It needs be mentioned that the 1974 GATT has now been replaced with the WTO in 1995 but its original effect (as modified in 1994) is still in operation under the WTO framework. The WTO on the other hand, works with norms/traditions of trade generally based on agreements which is why WTO agreements display some aspects aimed at preventing abuse of the global market, ${ }^{46}$ like infiltration of containers with WMD. This idea of preventing abuses of global market by WTO is never seen as being incongruous with economic interests of the participating states because security cannot be compromised for economic advantages. In this sense, a new regime by WTO would widen beyond merely focusing on the maritime aspects of terrorism. To a large extent, the United States had given recognition to this requirement in its representation to the IMO, maintaining that the obligation for maritime security goes beyond IMO's parameters of the maritime world, extending to land-based sources. Therefore, other stakeholders are required to develop effective overall security measures to accurately address this issue.

The only international legal provision that may represent a major impediment to the introduction of a new security regime vis-à-vis discrimination with regard to ships from certain countries appears in Article 5(2) of the General Agreement on Tariffs and Trade (GATT). Article 5(2) provides for Freedom of Transit through the territory of each member state, using the routes most suitable for international shipment and for

\footnotetext{
$44 \quad$ Bowman G.W, at p. 207.

$45 \quad$ Arup. C, The New World Trade Organization Agreements: Globalizing Law through Services and Intellectual Property, (United Kingdom: Cambridge University Press, 2000), p. 42. Ibid.
} 
traffic in transit to or from the territory of other contracting parties. The provision goes further to discourage discrimination against ships on the grounds of the place of origin, flag of ships, departure, destination, entry or exit or any circumstances to wit the ownership of goods, ships or other means of transport. The above could indicate that engaging in container profiling and discriminatory targeting of transshipment cargo from selected countries may in fact be contrary to the GATT agreement. It is no doubt that in the U.S. standpoint, it is obvious that ships carrying containers originating from Iraq or Afghanistan would be subjected to special and stringent examination by security officers.

There are security exceptions within the GATT agreement which favour the U.S standpoint as stated above. Article 21(b) permits a state to override the agreement in cases involving gun running, the trafficking of nuclear material or during a general time of emergency. Thus, this provision appears to suggest that security challenges in certain instances may be allowed to take precedence over other provisions of the agreement. For this reason, a new security system targeting specific ships and cargo as a matter of routine might not amount to a contravention of the agreement. Essentially, international organisations like WTO, WCO, etc have been established to carry out certain functions that are practically impracticable for states alone to discharge ${ }^{47}$ This will in a way address rapidly changing port and maritime security. The involvement of these international organisations will not erode states' sovereignty and it will not also prevent states from taking measures bordering on national security, as the states still control this process through their agencies like the Royal Malaysian Customs, Royal Malaysian Navy, etc.

\section{MALAYSIAN PORTS AS MAIN TRADE GATEWAYS AND NON-COMPROMISE OF SECURITY}

Ports are considered as the world's main trade gateways. However, port security which is synonymous with border security even from a maritime domain perspective makes its legal regime crucial to national, Revised Ed., (The Netherland: Martinus Nijhoff Publishers, 2011), p. 606. 
regional and international economic development. This is why port law sets out clear rules on public rights of utilisation of ports as illustrated in Roman law which to a large extent, has been integrated internationally as could be seen in international conventions and other informal coordination processes.

As it is observed elsewhere in this paper, a lot of economic benefits are attached to the establishment of ports. The economic fortune of a port state like Malaysia is not quantifiable and it is capable of creating employment opportunities in addition to other advantages such as generating income for the government, safer means of transportation of oil, etc. Malaysia as a port state is not oblivious of the attendant security implications of ships patronising its ports. Hence regulations have been put in place to guide shipping operations given that international security is not possible in absolute because of many factors pointing to the endless insecurity under the international system. ${ }^{48}$ The unfeasibility of international security has been the basis of certain actions by state parties to control and regulate activities in relation to international trade. For this reason, the issue of national security vis-à-vis economic gain is not compromised in international trade, regardless of the fact that international trade/maritime commerce brings about economic growth to a country. It is clear that in recent times port security remains a source of concern to virtually all port states including U.S, Australia, etc. The concern was a sequel to the 9/11 hijacking and bombing of the World Trade Centre and Pentagon. After this incident, the U.S continues to increase domestic port security which made her pass the Safe Port Act 2002 and U.S Trade Act 2002 with the aim of monitoring cargo. ${ }^{49}$ It is interesting to observe that maritime economic gain accounts for $50 \%$ of the United States' income ${ }^{50}$ but this was never considered to have priority over national security. Accordingly, various security measures ranging from laws to enforcement mechanisms have been put in place in order to prevent incidences like importation of Weapons of Mass Destruction. ${ }^{51}$

\footnotetext{
$48 \quad$ See generally, Buzan. B, at p. 31.

49 Guner-Ozbek M.D, The Carriage of Dangerous Goods by Sea, (Berlin: Springer, 2007), p. 115.

50 Ibid.

51 Conrad. S, et’al "How Do We Increase Port Security Without Imperilling Maritime Commerce? Using Flight Stimulators as Discussion,” available
} 
It is obvious that International law on maritime port grants foreign ships right of access to ports of other states ${ }^{52}$ but with a caution that port authorities are allowed to regulate ingress or even deny access to its port where security interests of the country concerned is at stake. ${ }^{53}$ This position was settled by the ICJ in the case of Saudi Arabia $v$ Arabian American Oil Company (ARAMCO) ${ }^{54}$ that a port state may decline access to its port where security of the country demands. Therefore, the above given power to port states spurred the promulgation of laws and establishment of port security agencies by the Malaysian government like navy, customs, marine police, immigration, etc with powers to board and inspect ships, ensure proper documentation of cargo and passengers, ${ }^{55}$ prohibition of disembarkation, ${ }^{56}$ receive notice of information on importation of dangerous cargo, ${ }^{57}$ etc. that are all concomitant with international practice ${ }^{58}$ It also supported efforts of the Malaysian government towards ensuring maximum protection of its port borders. Implementation of CSI, ISPS Code, CSI and other security measures in compliance with the IMO regulation also fall under this category. Accordingly, a ship that fails to comply with measures put in place by Malaysian port in compliance with the IMO regulations and Malaysian legislations may be denied access to port. The absence of these security agencies could have resulted in porous borders, thereby giving room to national insecurity.

Although it has been asserted that certain security measures put in place in ports like CSI hinder speedy clearance of cargoes, which has become a cause for concern to shippers because of the delay in clearing

\footnotetext{
at http://www.systemdynamics.org oceed/PAPERS/377.pdf (accessed on $30 / 8 / 12$ ). See the 1923 International Convention and Statute on Maritime Ports, Article 2.

Ibid, Article 3. See also Kaye. S, "Threats from the Global Commons: Problems of Jurisdiction and Enforcement,” (2007) Vol. 8, Melbourne Journal of International Law, and Oliver J.T. id, p. 209-21. (1958) 27 I.L.R 117. See also Kaye. S, id and Oliver J.T. id, p. 209-21. See the Merchant Shipping Act, section 249A. Immigration Act 1959/1963, section 19. See the Customs Act, 1967, section 37(1) and (2) and section 29(2) of the Port Authority Act, 1963 (Act no 488).

Guilfoyle. D, Shipping Interdiction and the Law of the Law, (United Kingdom: Cambridge University Press, 2009), p. 9.
} 
their cargo, national security cannot be compromised for economic gain. ${ }^{59}$ Therefore, security as a matter of fact takes precedence over economic gain as economic gain may not be capable of remedying losses arising from national insecurity. For example, where microbes (bio-terrorism) are released by attackers in a port due to gaps in the security arrangements, it may lead to death of thousands of innocent citizens. What economic gain is capable of redeeming lives which would have been lost in such a circumstance? All ships (except government or war ships which are excluded under UNCLOS $)^{60}$ including holiday cruisers, passenger ships, etc are subject to inspection by port security agents, otherwise the scenario that occurred in the case of Atlantic Mutual Assurance Co. v. King, ${ }^{61}$ may repeat itself. In that case a ship loaded at Bahia, Brazil exploded as a result of explosives placed on board which resulted in the death of three seamen and wrecked part of the ship. Upon investigation, it was revealed that the explosives had been placed on the vessel at the loading port by a German national with the aid of accomplices. Therefore, excluding holiday cruisers from thorough inspection by port security agencies may be disastrous to port state like Malaysia.

From an economic perspective, port security is significant to Malaysia because of the fact that major Malaysian ports are located on the Straits of Malacca, and protection of fishing and tourism industries cannot be over-emphasised. Notwithstanding the economic advantages in fishing and tourism industries, there is a need to take appropriate monitoring and surveillance on tourists as they could be saboteurs/ attackers $^{62}$ in disguise as was the case in the Achille Lauro incident. In this famous incident, the attackers posed as tourists but changed and made their mission known on shore when they threw a passenger with his wheelchair into the sea in order to achieve their ends. Therefore, failure to take appropriate security measures could adversely affect national security and marine natural resources.

\footnotetext{
$59 \quad$ Conrad.

60 See Article 32 of the 1982 UNCLOS. See also Klein N., Maritime Security and Law of the Sea, (New York: Oxford University Press, 2011), p. 30.

61 (1919) 1 KB 307. See also Michel K, War, Terror and Carriage by Sea, (Great Britain: LLP, 2004), p. 55.

62 Ibid.
} 
Security is precious to any responsible government because adequate security brings about stability and economic development, that in turn fosters a social environment whereby individual citizens as well as others can grow. ${ }^{63}$ IThus security offers to citizens and non-citizens a stable framework and conditions for the pursuit of their business. The events of September 11, 2001 in U.S constituted a serious failure of security $^{64}$ at various U.S airports, hence if adequate measures are not put in place, the same scenario may repeat itself in port. The issue should not be restricted to security procedures but also the larger federal security processes that are directed towards terrorism and threats to security of a nation. ${ }^{65}$ Security failure naturally raises questions concerning the adequacy, effectiveness and efficiency of security at both local and federal levels. ${ }^{66}$

$63 \quad$ Ibid. This is possible at least in theory.

$64 \quad$ See Rabasa. A and Chalk. P, Non-Traditional Threats and Maritime Domain Awareness in the Tri-Border Area of Southeast Asia: The Coast Watch System of the Philippines, (Pittsburgh: RAND Corporation, 2012) p. 5. See also Ding S.A, “Taiwan: The Prevalence of Traditional Security Issues,” in Edstrom. B, (ed), Security and Development in Asia, (Singapore: Institute for Security and Development Policy, 2009), p. 23 and Butfoy. A, Common Security and Strategic Reform: A Critical Analysis (New York: St. Martin's Press, 1997) and Bush. R, Untying the Knot: Making Peace in the Taiwan Strait, (Washington: Brooking Institution Press, 2005), p. 27.

Ibid.

In October 1985, the hijacking of the Italian cruise ship Achille Lauro marked one of the first actual terrorist acts recorded in modern maritime history. Following that incident, the International Maritime Organization (IMO) issued measures to prevent unlawful acts against passengers and crew on board ships. The IMO, headquartered in London, is a specialized agency of the United Nations which is responsible for measures to improve the safety and security of international shipping and to prevent marine pollution from ships. IMO is also involved in legal matters, including liability and compensation issues, and the facilitation of international maritime traffic. IMO was established under the auspices of the United Nations in Geneva on March 17, 1948 and met for the first time in January 1959.72 After the Achille Lauro, the IMO Convention with 165 signatory countries ensures that appropriateaction is taken against persons committing unlawful acts 


\section{CONCLUSION}

It is apparent that the seas surrounding the land play an important role in the economic, defence and political matters of the state thus endowed. Malaysia presently has a plethora of maritime laws which regulate transportation and movement of cargo and passengers through its seas and port borders. Malaysia is one of the counties that value its border security either at sea ports or airports. This has prompted Malaysia to become involved directly in pursuing national interests at the international level regarding maritime jurisdiction, in order to ensure security and selfpreservation, resource exploration and exploitation and political well-being. To achieve the above, Malaysia had earlier adopted the Sectoral Approach in formulating maritime or ocean related laws for the administration of the maritime sector. However, due to the overlapping of functions and jurisdictions, the sectoral approach was dropped for Singular Approach with the establishment of the MMEA. All these measures made towards ensuring economic gains are not compromises for national security, which could be effected through port insecurity. This paper recommends that the idea of preventing abuse of global market by WTO should never be seen as being incongruous with economic interests of the participating states because security cannot be compromised for economic advantages. In essence, where a ship is seen likely to contribute toe national insecurity of Malaysia, based on the numerous domestic legislations and the decision of the ICJ in Saudi Arabia $v$ ARAMCO, such a ship may be disallowed from entry to Malaysian ports despite the loss of economic gain. The need to decline entry to a vulnerable ship is premised on the fact that economic gain from a ship may not be capable of restoring national security which would have eluded a nation due to importation of dangerous cargo or weapons of mass destruction. Although various security measures put in place in ports like CSI may appear to hinder speedy clearance of cargo becoming a matter of concern to shippers because of the delay caused in clearing their cargo, national security cannot be compromised for economic gain.

against ships. Such illegal acts include the seizure of ships by force, acts of violence against persons on board ships, etc. See generally Klein. K. 